\title{
ANALISIS PENENTUAN HARGA POKOK PRODUKSI DENGAN PENERAPAN ACTIVITY BASED COSTING (Studi Kasus pada PT. Peni Regency Tahun 2019)
}

\author{
Niken Anugraheni Mutiah ${ }^{1}$, Widi Hariyanti ${ }^{2}$, Yunus Harjito ${ }^{3}$ \\ Program Studi Akuntansi, Fakultas Ekonomi, Universitas Setia Budi Surakarta

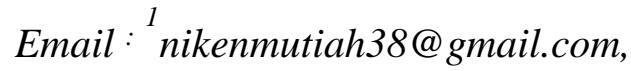

\begin{abstract}
The results of this study aim to determine: (1) Calculation of Cost of Production used by PT. Peni Regency. (2) Calculation of Cost of Production with Activity Based Costing at PT. Peni Regency. (3) To analyze the differences in the methods used at PT. Peni Regency or the Activity Based Costing method in determining the Cost of Production. The results obtained from this study are the Cost of Production using the Activity Based Costing method, namely for Type 36/63 Rp 1,123,279.70, for type 45/84 which is Rp 4,626,470.84, Type 52/112 which is Rp (6.60 .6,477.11), Type 60/120 i.e. Rp. 856,726.57. The difference that occurs with the calculation of the cost of production used in PT. Peni Regency and Activity Based Costing methods occur due to BOP loading. In the traditional BOP method, each unit is only charged to one cost driver, namely the development unit, which causes BOP distortion, thereby causing a development overhead burden that comes from one cost trigger, namely the unit built. With the Activity Based Costing can improve the quality of decision making so that it can help the management in improving strategic planning.
\end{abstract}

Keywords : Cost of Production, Method of PT. Peni Regency, Activity Based Costing methods.

\section{PENDAHULUAN}

Suatu perusahaan ingin mempunyai peningkatan profitabilitas dari waktu ke waktu. Bukan hanya sekedar meningkatkan profitabilitas namun harus berani bersaing dengan pesaing-pesaing yang kompetitif yang ada saat ini. Persaingan kompetitif product juga dihadapi oleh perusahaan yang bergerak di bidang properti. Properti yang dimaksud ini adalah perumahan, perumahan menjadi kebutuhan penting bagi masyarakat sebab rumah bukan hanya sekedar tempat berlindung dari kehujanan, kepanasan, tetapi rumah bisa menjadi tempat yang memberikan kenyamanan, aman sebagai tempat berlindung sehari- hari. Contoh dari perusahaan yang bergerak di bidang properti yaitu PT. Peni Regency yang berada di Solo Baru.

PT. Peni Regency masih menggunakan metode tradisional sebagai perhitungan dalam menentukan Harga Pokok Produksi. Sistem biaya tradisional mengalokasikan semua overhead manufakhtur secara tradisional berdasarkan satu tingkat organisasi. Biaya Tradisional adalah perhitungan biaya produk dengan membebankan biaya dari bahan baku langsung dan tenaga kerja langsung pada produk dan biaya overhead dibebankan dengan menggunakan penggerak aktivitas unit. Penggerak aktivitas unit adalah faktor-faktor yang menyebabkan perubahan dalam biaya seiring dengan perubahan jumlah unit yang diproduksi. PT. Peni Regency masih 
menggunakan metode tradisional yaitu dengan memperhitungkan biaya produk atau harga pokok produksi yang membebankan biaya overhead berdasarkan unit atau volume yang diproduksi.

Harga Pokok Produksi merupakan peranan yang sangat penting. Menurut Mulyadi (2014) harga pokok produksi atau disebut harga pokok adalah sumber ekonomi yang diukur dalam satuan uang yang telah terjadi atau kemungkinan terjadi untuk memperoleh penghasilan. Harga pokok produksi akan sama dengan biaya produksi apabila tidak ada persediaan produk dalam proses awal dan akhir. Bahwa harga pokok produksi (cost of good manufactured) memperhitungkan total biaya barang yang diselesaikan selama periode berjalan.

Activity Based Costing system merupakan salah satu cara untuk meningkatkan informasi biaya dari sistem tradisional. Menurut Mulyadi (2003) Activity Based Costing ini memiliki penerapan penelusuran biaya yang lebih menyeluruh, lebih akurat dan relevan dibandingkan dengan akuntansi biaya tradisional. Dalam metode ini, pembebanan pada harga pokok produksi merupakan penjumlahan dari setiap biaya-biaya aktivitas yang dapat menghasilkan barang/jasa sebagai harga jual produk. Sebagai dasar yang digunakan adalah jumlah aktivitas dalam setiap masing-masing kelompok biaya (cost pool). Metode ini, menggunakan jenis pemicu biaya yang lebih banyak sehingga dapat mengukur sumber daya yang digunakan oleh produk lebih akurat.

Apabila Perusahaan yang dapat menetapkan harga jual dengan tepat dan perusahaan dapat menghitung harga pokok produksi dengan tepat sehingga harga yang diperoleh/harga yang diberikan kepada konsumen tidak overcosted (biaya yang dibebani lebih pada harga seharusnya) dan tidak juga undercosted (biaya yang dibebani kurang dari biaya yang seharusnya). PT. Peni Regency ini adalah salah satu perusahaan yang belum menggunakan metode activity based costing dan masih menggunakan metode tradisional (Rina, 2019).

Berdasarkan latar belakang dalam penelitian ini, peneliti tertarik untuk melakukan sebuah penelitian dengan judul Analisis Penentuan Harga Pokok Produksi dengan Penerapan Activity Based Costing (Studi kasus pada PT. Peni Regency Tahun 2019). Penelitian ini dilakukan dengan membandingkan metode tradisional dengan metode Activity Based Costing untuk mengetahui hasil yang diperoleh dapat efektif atau tidak efektif dengan mengkaitkan hasil perhitungan Activity Based Costing dengan metode tradisional dengan indikator target costing pada perusahaan.

\section{Perumusan Masalah}

Berdasarkan uraian latar belakang diatas, permasalahan dalam penelitian ini yaitu PT. Peni Regency masih menggunakan metode tradisional yang dirasa belum efektif digunakan dalam penentuan harga pokok produksi apabila dibandingkan dengan metode Activity Based Costing. Hasil penelitian yang menyatakan bahwa metode ABC lebih efektif digunakan dibandingkan metode tradisional yaitu penelitian Nanda (2018), Rahmadani (2016), Wulansari (2012), dan Raba' (2013). Sehingga, rumusan masalah pada penelitian ini adalah: "Bagaimana penentuan Harga Pokok Produksi dengan Metode Activity Based Costing pada PT. Peni Regency?" 


\section{Tinjauan Teoritis}

Akuntansi Biaya adalah proses pencatatan, pengelompokan, peringkasan dan penyajian biaya yang berkaitan dengan proses pembuatan dan penjualan produk atau jasa dengan cara-cara tertentu. Akuntansi Biaya merupakan suatu bidang ilmu yang mempelajari tentang penyediaan informasi yang dibutuhkan oleh akuntansi keuangan dan manajemen perusahaan. Dengan adanya informasi yang baik dapat berkaitan dengan akuntansi keuangan maupun akuntansi non keuangan.

Akuntansi biaya tradisional dibagi menjadi dua tipe Menurut Mulyadi (2015): (1) akuntansi biaya dengan fokus ke perhitungan biaya produk dan (2) akuntansi pertanggungjawaban. Kedua tipe akuntansi biaya perhitungan tersebut dikembangkan pada waktu pengolahan data akuntansi. Dilaksanakan secara manual (tulisan tangan). Akuntansi biaya tradisional didesain untuk perusahaan manufakhtur perusahaan yang kegiatan pokoknya mengolah bahan baku menjadi produk jadi dan menjual produk jadi tersebut kepada customer. Pada awal perkembangannya, akuntansi biaya hanya difokuskan pada perhitungan kos produk (product costing) yang dihasilkan oleh perusahaan manufaktur. Pada perkembangan selanjutnya, akuntansi biaya difokuskan pada pengendalian biaya melalui akuntansi pertanggungjawaban. Dalam akuntansi pertanggungjawaban ini, biaya dihubungkan dengan manajer yang memiliki wewenang atas biaya tertentu, agar manajer tersebut dapat merencanakan dan mengendalikan biaya yang menjadi tanggung jawabnya.

Menurut Mulyadi (2003), pada tahap awal perkembangannya Activity Based Costing dimanfaatkan untuk memperbaiki perhitungan kos produk dalam perusahaan-perusahaan manufaktur yang menghasilkan banyak jenis produk. Masalah yang dihadapi perusahaan yang menghasilkan banyak jenis produk adalah pada pembebanan biaya overhead pabrik ke berbagai jenis produk yang dihasilkan oleh perusahaan. Akuntansi biaya tradisional hanya menggunakan volume-related drivers untuk membebankan biaya overhead pabrik ke produk, sehingga kos produk yang dihasilkan dari cara pembebanan ini menjadi tidak akurat. Activity Based Costing system menawarkan dasar pembebanan yang lebih bervariasi, seperti batch-related drivers, product-sustaining drivers, dan facility-sustaining drivers untuk membebankan biaya overhead pabrik kepada berbagai jenis produk yang dihasilkan, akuntansi biaya dapat menghasilkan infomasi kos produk yang akurat, sehingga memungkinkan manajemen mengambil keputusan tentang harga jual dan melakukan analisis profitabilitas setiap jenis produk.

Target costing atau biaya produk sasaran adalah strategi yang digunakan oleh perusahaan yang pertama untuk menetapkan harga jual dimana perusahaan dapat menjual produk atau jasa baru, dan kemudian merancang produk atau jasa yang dapat di produksi pada suatu biaya yang cukup rendah guna memberikan margin laba yang memadai. Metode ini diterapkan untuk mencapai berbagai departemen yang terlibat dalam desain dan produksi dalam upaya mencari cara-cara yang lebih mudah untuk mencapai keistimewaan dan mutu produk yang sama atau lebih baik. Target costing digunakan selama tahap perencanaan dan menuntun dalam pemilihan produk serta proses desain yang akan dihasilkan suatu produk yang dapat diproduksi pada biaya yang diperbolehkan dan pada suatu tingkat laba yang diterima. Target costing juga memberikan perkiraan harga pasar produk, volume penjualan, dan tingkat fungsionalitas (Caroline, 2016). 


\section{Kerangka Pikir}

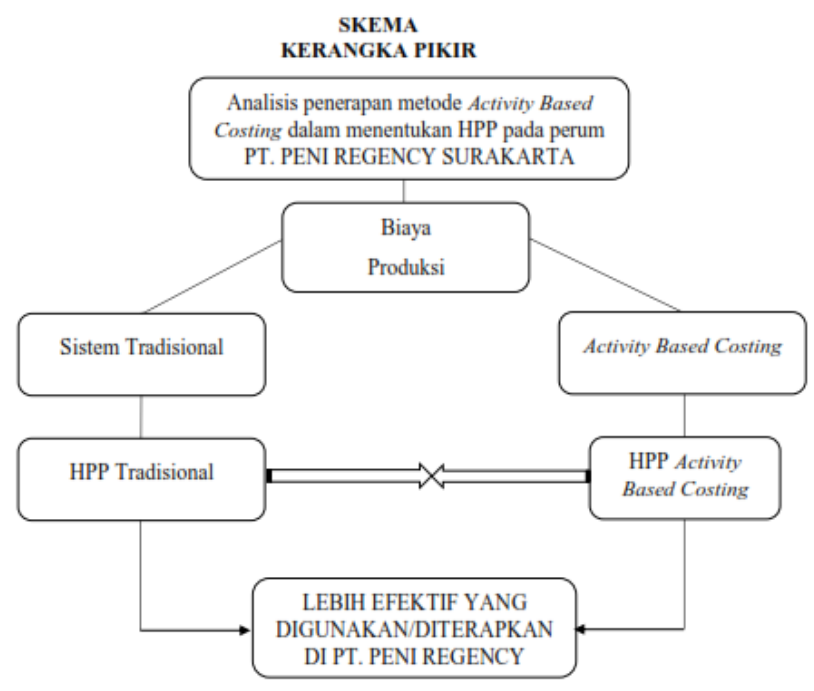

Perbandingan dengan metode Activity Based Costing dengan Sistem tradisional yang digunakan di Perum PT. PENI REGENCY

Setelah dilakukan perhitungan dengan menggunakan Metode Activity Based Costing dengan Sistem Tradisional manakah yang lebih efektif untuk digunakan dalam menentukan besarnya HPP.

\section{METODE PENELITIAN}

Penelitian ini merupakan penelitian Semi Kualitatif, dimana dalam penelitian ini data diambil berupa data kualitatif \& data kuantitatif. Data kualitatif diperoleh penulis melalui metode wawancara langsung dan pengamatan. Data kuantitatif diperoleh peneliti dari data keuangan atau laporan keungan PT. Peni Regency. Penelitian ini menggunakan PT. Peni Regency sebagai objek penelitian dengan membandingkan perhitungan Harga Pokok Produksi dari metode Activity Based Costing dan metode Tradisional. PT. Peni Regency berada di Surakarta yaitu pusatnya yang di Solo Baru. Alasan pemilihan PT. Peni Regency sebagai tempat penelitian karena PT. Peni Regency masih menggunakan model konvensional/metode tradisional dalam penentuan Harga Pokok Produksinya

\section{Populasi dan Sampel Penelitian}

Populasi yaitu wilayah generalisasi yang terdiri dari objek atau subjek yang mempunyai kuantitas dan karakteristik tertentu yang ditetapkan oleh peneliti untuk dipelajari kemudian ditarik kesimpulannya (Sugiyono, 2019).

Sampel yang diambil dari populasi tersebut harus betul-betul representative (mewakili) (Sugiyono, 2018:81). Sampel pada penelitian ini menggunakan 1 objek penelitian atau 1 perusahaan yaitu PT. Peni Regency. Penelitian ini membandingkan Penentuan Harga Pokok Produksi antara Metode tradisional dengan metode Activity Based Costing. Data yang dianalisis menggunakan data sekunder yang secara langsung diambil dari PT. Peni Regency. 


\section{HASIL DAN PEMBAHASAN}

\subsection{Hasil Penelitian}

\section{Perhitungan Harga Pokok Produksi PT. Peni Regency}

Harga pokok produksi adalah keseluruh biaya yang dikeluarkan dalam satuan uang untuk proses pembangunan dari bahan baku menjadi barang jadi yang siap untuk dijual yang terdiri dari biaya langsung, biaya tenaga kerja langsung dan biaya overhead pabrik. Menurut Mulyadi (2003) harga pokok produksi atau disebut harga pokok adalah sumber ekonomi yang diukur dalam satuan uang yang telah untuk memperoleh penghasilan. Untuk menentukan Harga Pokok Produksi per type/unit rumah, PT. Peni Regency menggunakan metode yang digunakan sendiri oleh PT. Peni Regency yang sudah berjalan hingga sekarang ini. Metode yang digunakan oleh PT. Peni Regency tersebut sering disebut dengan metode tradisional/sama halnya dengan perhitungan metode tradisional. Penjelasan ini diperoleh peneliti dari bagian Accounting di PT. Peni Regency yaitu dalan menentukan Harga Pokok Produksi hanya dengan menambah biayabiaya, yaitu biaya yang digunakan biaya bahan baku, biaya tenaga kerja langsung dan biaya overhead pabrik. Kemudian, biaya tersebut ditotal secara keseluruhan dibagi berdasarkan unit/per type rumah. Sehingga, Harga Pokok Produksi diperoleh dari perhitungan tersebut. Faktor utama yang digunakan oleh perusahaan dalam penentuan Harga Pokok Produksi yaitu biaya bahan baku dan biaya tenaga kerja langsung, atau menggunakan driver berlevel unit yaitu dengan membebankan biaya aktivitas berdasarkan unit.

Tabel 1

Penentuan Harga Pokok Produksi Per Unit/Type

\begin{tabular}{|c|c|}
\hline \multicolumn{2}{|c|}{ Type } \\
\hline Bahan Baku & Rp $\quad 693.000 .000$ \\
\hline Biaya Tenaga Kerja Langsung & $\begin{array}{ll}\mathrm{Rp} & 606.375 .000\end{array}$ \\
\hline Biaya Overhead Pabrik & $\begin{array}{ll}\mathrm{Rp} & 61.875 .000 \\
\end{array}$ \\
\hline Harga Pokok Produksi & $\operatorname{Rp} 1.361 .250 .000$ \\
\hline Unit & 7 Unit \\
\hline Harga Pokok Produksi/Unit & Rp 194.464,286 \\
\hline \multicolumn{2}{|l|}{ 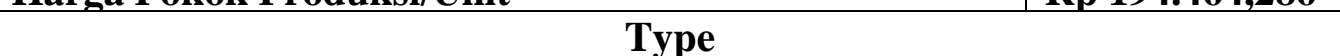 } \\
\hline Bahan Baku & Rp 705.600 .000 \\
\hline Biaya Tenaga Kerja Langsung & $\operatorname{Rp} 617.400 .000$ \\
\hline Biaya Overhead Pabrik & Rp 73.500 .000 \\
\hline Harga Pokok Produksi & Rp 1.396.500.000 \\
\hline Unit & 6 Unit \\
\hline Harga Pokok Produksi/Unit & Rp 232.750.000 \\
\hline \multicolumn{2}{|c|}{ Type } \\
\hline Bahan Baku & Rp 748.800 .000 \\
\hline Biaya Tenaga Kerja Langsung & $\operatorname{Rp} 655.200 .000$ \\
\hline Biaya Overhead Pabrik & Rp 78.000 .000 \\
\hline Harga Pokok Produksi & $\mathrm{Rp} 1.482 .000 .000$ \\
\hline Unit & 6 Unit \\
\hline Harga Pokok Produksi/Unit & Rp 247.000.000 \\
\hline \multicolumn{2}{|l|}{ 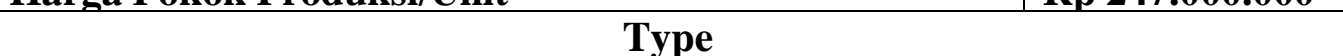 } \\
\hline Bahan Baku & $\mathrm{Rp} 1.365 .000 .000$ \\
\hline Biaya Tenaga Kerja Langsung & $\operatorname{Rp} 1.195 .375 .000$ \\
\hline
\end{tabular}




\begin{tabular}{|l|l|}
\hline Biaya Overhead Pabrik & $\mathrm{Rp} 93.870 .000$ \\
\hline Harga Pokok Produksi & $\mathrm{Rp} \mathrm{2.653.245.000}$ \\
\hline Unit & 7 Unit \\
\hline Harga Pokok Produksi/Unit & Rp 379.035.000 \\
\hline
\end{tabular}

Sumber : PT. Peni Regency

Dari perhitungan yang telah ditetapkan oleh PT. Peni Regency tersebut, penentuan Harga Pokok Produksi diperoleh dari penjumlahan antara Biaya Bahan Baku, Biaya Tenaga Kerja Langsung, dan BOP kemudian hasil nya Harga Pokok Produksi, dibagi per unit. Hasil dari pembagian tersebut merupakan Harga Pokok Produksi per unit. Untuk type 36/63 HPP per unit yaitu Rp 194.464.286. untuk type 45/84 HPP per unit yaitu Rp 232.750.000, untuk type 52/112 HPP Per unit yaitu Rp 247.000.000, untuk type 60/120 HPP Per unit yaitu Rp 379.035.000.

\section{Penerapan Target Costing pada PT. Peni Regency}

Target Costing untuk pembangunan Unit perumahan PT. Peni Regency dapat dihitung dengan cara mengurangi harga jual dengan laba yang di inginkan oleh perusahaan. PT. Peni Regency menginginkan Laba yang diharapkan dari penjualan per unit type rumah sebesar $25 \%$ dari harga jual dari setiap unit type rumah.

Tabel 2

Target Costing PT. Peni Regency Tahun 2019

\begin{tabular}{|c|c|c|}
\hline No. & Jenis & Target Costing \\
\hline \multirow{5}{*}{1.} & \multicolumn{2}{|l|}{ Type } \\
\hline & Harga Kompetitif/Harga Jual & Rp 330.000.000 \\
\hline & Laba yang diinginkan $25 \%$ dari Harga Jual & $\operatorname{Rp} 82.500 .000$ \\
\hline & Per Unit & $\operatorname{Rp} 247.500 .000$ \\
\hline & Tahun 2019, 7 Unit & 1.732 .500 .000 \\
\hline No. & Jenis & Target Costing \\
\hline \multirow[b]{5}{*}{2.} & \multicolumn{2}{|l|}{ Type } \\
\hline & Harga Kompetitif/Harga Jual & $\operatorname{Rp} 420.000 .000$ \\
\hline & Laba yang diinginkan $25 \%$ dari Harga Jual & Rp 105.00.000 \\
\hline & Per Unit & $\operatorname{Rp} 315.000 .000$ \\
\hline & Tahun 2019, 6 Unit & 1.890 .000 .000 \\
\hline No. & Jenis & Target Costing \\
\hline \multirow{5}{*}{3.} & \multicolumn{2}{|l|}{ Type } \\
\hline & Harga Kompetitif/Harga Jual & $\mathrm{Rp} 520.000 .000$ \\
\hline & Laba yang diinginkan $25 \%$ dari Harga Jual & Rp 130.000 .000 \\
\hline & Per Unit & $\operatorname{Rp} 390.000 .000$ \\
\hline & Tahun 2019, 6 Unit & $\mathrm{Rp} 2.320 .000 .000$ \\
\hline No. & Jenis & Target Costing \\
\hline \multirow{5}{*}{4.} & \multicolumn{2}{|l|}{ Type } \\
\hline & Harga Kompetitif/Harga Jual & $\operatorname{Rp} 650.000 .000$ \\
\hline & Laba yang diinginkan $25 \%$ dari Harga Jual & $\mathrm{Rp} 162.500 .000$ \\
\hline & Per Unit & $\mathrm{Rp} 487.500 .000$ \\
\hline & Tahun 2019, 7 Unit & Rp 3.412.500.000 \\
\hline
\end{tabular}


Berdasarkan perhitungan diatas, target costing yang dihasilkan pada PT. Peni Regency yaitu untuk Type 36/63 Rp 1.732.500.000 per tahun, untuk Type 45/84 sebesar Rp 1.890.000.000, untuk Type 52/112 sebesar Rp 2.340.000.000, untuk Type 60/120 sebesar Rp 3.412.500.000.

\section{Harga Pokok Produksi menggunakan Metode Activity Based Costing}

Metode lain sebagai alternatif yang dapat digunakan oleh perusahaan, dapat menerapkan Activity Based Costing yang berdasarkan aktivitas sehingga penentuan harga pokok produksi lebih akurat. Activity Based Costing mendasarkan bahwa jika produk mengkonsumsi banyak sumber daya overhead (memakai banyak aktivitas), maka produk tersebut harus menanggung biaya overhead pabrik yang lebih besar dari produk lain yang hanya mengkonsumsi sumber daya sedikit.

Tabel 3

Perhitungan Harga Pokok Produksi dengan Activity Based Costing

\begin{tabular}{|c|c|}
\hline \multicolumn{2}{|c|}{ Type } \\
\hline Bahan Baku & Rp 693.000.000 \\
\hline Biaya Tenaga Kerja Langsung & Rp 606.375.000 \\
\hline Biaya Overhead Pabrik & Rp 60.751 .720 \\
\hline Harga Pokok Produksi & Rp 1.360.126.720 \\
\hline Unit & 7 Unit \\
\hline Harga Pokok Produksi/Unit & Rp 194.308817 \\
\hline \multicolumn{2}{|c|}{ Type } \\
\hline Bahan Baku & Rp 705.600.000 \\
\hline Biaya Tenaga Kerja Langsung & Rp 617.400.000 \\
\hline Biaya Overhead Pabrik & Rp 68.873.529 \\
\hline Harga Pokok Produksi & Rp 1.391.873.529 \\
\hline Unit & 6 Unit \\
\hline Harga Pokok Produksi/Unit & Rp 231.978.922 \\
\hline \multicolumn{2}{|c|}{ Type } \\
\hline Bahan Baku & 748.800 .000 \\
\hline Biaya Tenaga Kerja Langsung & 655.200 .000 \\
\hline Biaya Overhead Pabrik & 84.606 .477 \\
\hline Harga Pokok Produksi & 1.488 .606 .477 \\
\hline Unit & 6 Unit \\
\hline Harga Pokok Produksi/Unit & 248.101 .080 \\
\hline \multicolumn{2}{|c|}{ Type } \\
\hline Bahan Baku & 1.365 .000 .000 \\
\hline Biaya Tenaga Kerja Langsung & 1.194 .375 .000 \\
\hline Biaya Overhead Pabrik & 93.013 .273 \\
\hline Harga Pokok Produksi & 2.652 .388 .273 \\
\hline
\end{tabular}




\begin{tabular}{|l|l|}
\hline Unit & 7 Unit \\
\hline Harga Pokok Produksi/Unit & $\mathbf{3 7 8 . 9 1 2 . 6 1 0}$ \\
\hline
\end{tabular}

Sumber : Data Sekunder Diolah

Berdasarkan perhitungan Harga Pokok Produksi dengan Activity Based Costing, Untuk Harga Pokok Produksi type 36/63 hasilnya Rp 194.303.817, untuk Harga Pokok Produksi type 45/84 hasilnya Rp 231.978.922, untuk type 52/112 Harga Pokok Produksi hasilnya Rp 248.101.080, untuk type 60/120 Harga Pokok Produksi per unit Rp 378.912.610. Setelah dilakukan perhitungan HPP dengan metode tradisional dan Activity Based Costing per unit. Langkah selanjutnya, yaitu dengan melakukan perbandingan antara HPP metode Tradisional dan Metode Activity Based Costing.

\section{Pembahasan}

Tabel 4

Perbandingan Target Costing, PT. Peni Regency dan Activity Based Costing

\begin{tabular}{|l|l|c|c|}
\hline Type & Target Costing & PT. Peni Regency & Activity Based Costing \\
\hline Type 36/63 & $\mathrm{Rp}$ & $\mathrm{Rp} \mathrm{1.361.250.000}$ & $\mathrm{Rp} \mathrm{1.360.126.720}$ \\
\hline Type 45/84 & $\mathrm{Rp}$ & $\mathrm{Rp} \mathrm{1.396.500.000}$ & $\mathrm{Rp} \mathrm{1.391.873.529}$ \\
\hline Type 52/112 & $\mathrm{Rp}$ & $\mathrm{Rp} \mathrm{1.482.000.000}$ & $\mathrm{Rp} \mathrm{1.488.606.477}$ \\
\hline Type 60/120 & $\mathrm{Rp}$ & $\mathrm{Rp} \mathrm{2.653.245.000}$ & $\mathrm{Rp} \mathrm{2.652.388.273}$ \\
\hline
\end{tabular}

Sumber : Data Sekunder Diolah

Berdasarkan perbandingan Harga Pokok Produksi yang PT. Peni Regency dan Activity Based Costing, Target Costing menunjukan bahwa perhitungan Activity Based Costing lebih rendah untuk Type 36/63 , Type 45/84, Type 60/120 dan untuk Type 52/112 memperoleh perhitungan yang tinggi. Perbedaan tersebut terjadi antara harga pokok produksi menggunakan metode yang digunakan PT. Peni Regency dan metode Activity Based Costing disebabkan karena pembebanan biaya overhead pabrik pada masing-masing produk. Perhitungan menggunakan activity based costing system lebih akurat dan tepat dibandingkan menggunakan metode PT. Peni Regency untuk type 36/63, type 45/84, tdan type 60/120. Sehingga perhitungan harga pokok produksi dengan Activity Based Costing diharapkan bisa membantu perusahaan untuk mengambil keputusan yang tepat khususnya dalam menghitung harga pokok produksi dan penetapan harga jual produk.

Berdasarkan hasil analisis, diketahui bahwa hasil perhitungan harga pokok produksi dengan metode Activity Based Costing lebih akurat untuk type 36/63, type 45/84, dan type 60/120 untuk type 36/63, type 45/84, dan type 60/120 digunakan oleh perusahaan untuk memperoleh laba yang diinginkan dibandingkan dengan metode PT. Peni Regency, karena metode Activity Based Costing lebih rinci dalam pengalokasian biaya bahan baku, biaya tenaga kerja dan biaya overhead pabrik. Dengan demikian, target costing yang dihasilkan lebih tinggi untuk target costing Activity Based Costing dari metode PT. Peni Regency. Indikator ini bisa 
menjadi pertimbangan untuk perusahaan/pihak manajemen perusahaan untuk menjadikan metode activity based costing dalam penentuan Harga Pokok Produksi untuk type 36/63, type 45/84, dan type 60/120 yang digunakan oleh PT. Peni Regency. Namun untuk type 52/112 sudah tepat dalam menentukan harga pokok produksi yang telah digunakan di PT. Peni Regency.

\section{KESIMPULAN}

1) Perhitungan dengan Harga Pokok Produksi yang digunakan oleh PT. Peni Regency belum efektif digunakan untuk Type 36/63, Type 45/84, Type 60/120.

2) Perhitungan dengan Harga Pokok Produksi menggunakan Activity Based Costing lebih efektif untuk Type 36/63, Type 45/84, Type 60/120, sedangkan untuk Type 52/112 lebih efektif dengan menggunakan metode PT. Peni Regency.

3) Dengan menggunakan Indikator Target Costing, Harga Pokok Produksi yang digunakan dengan metode Activity Based Costing lebih efektif untuk Type 36/63, Type 45/84, Type 60/120, dan dengan menggunakan metode yanh digunakan oleh PT. Peni Regency lebih efektif untuk Type 52/112.

\section{Saran}

Berdasarkan hasil analisa dan pembahasan yang telah dilakukan maka terdapat beberapa hal yang dapat disarankan, antara lain:

1) Dengan adanya penerapan metode activity based costing tidak hanya memahami secara detail teknisnya saja. Diperlukan adanya dukungan dari manajemen puncak dan juga para manajer yang terkait untuk bekerja sama dan mengambil inisiatif untuk menerapkan sistem activity based costing, karena itu adanya keterlibatan para manajer dalam implementasi activity based costing yang akan menciptakan peluang yang lebih besar untuk berkoordinasi dan bekerja sama antar fungsi yang berbeda.

2) b. Harga pokok produksi yang menggunakan metode activity based costing untuk Type 36/63, Type 45/84, Type 60/120 pada PT. Peni Regency menunjukan bahwa hasilnya lebih efektif, lebih efisien daripada hasil yang digunakan oleh PT. Peni Regency. Dan untuk Type 52/112 lebih efektif, lebih efisien dengan menggunakan metode yang digunakan oleh PT. Peni Regency karena harga pokok produksi yang dihasilkan lebih akurat, lebih efisien daripada menggunakan Activity Based Costing hal tersebut akan mempengaruhi harga jual dengan pesaing.

\section{DAFTAR PUSTAKA}

Arikunto, Suharsimi. 2014. Prosedur Penelitian (Suatu Pendekatan Praktik). Jakarta: Rineka Cipta. (Buku).

Caroline C.T dan Wokas N.RH. 2016. Analisis Penerapan Target Costing Dan ActivityBased Costing Sebagai Alat Bantu Manajemen Dalam Pengendalian Biaya Produksi 
Pada Ud. Bogor Bakery. Jurnal EMBA 593 Vol.4 No.1

Hansen Don. R dan Mowen Maryanne. M. (2006). Cost Management Accounting dan \& Control. Fifth Edition: Thomson.

Gerungan Henri Paulus. 2013. Pendekatan Target Costing sebagai Alat Penilaian Efisiensi Produksi pada PT. Tropica Cocoprima. Jurnal EMBA Vol. 1 No. 3 September 2013, Hal, 863-870.

Islahuzzaman. 2011. Activity Based Costing Teori dan Aplikasi. Alfabeta: Bandung. Kaunang dan Walandouw. 2015. Penerapan Metode Activity Based Costing System dalam menentukan besarnya tarif jasa rawat inap pada rumah sakit umum Bethesda kota Tomohon. Jurnal Emba vol.3 no.1 Maret 2015, hal.1214-1221

Kindangen, Morasa, Mawikere. 2018. Penerapan Activity Based Costing system dalam penentuan Harga Pokok Sewa tarif penyewaaan jasa kendaraan pada PT. Serasi Autoraya. Jurnal Riset Akuntansi Going Concern 13(4), 2018

Maulana Ardi Helmy, dkk. 2016. Analisis Activity Based Costing System (abc system) Sebagai dasar menentukan harga pokok kamar hotel (Studi Kasus pada Hotel Selecta Kota Batu Tahun 2014). Jurnal Administrasi Bisnis (JAB)|Vol. 30 No. 1 Januari 2016

Mulyadi. 2003. Activity Based Cost System. Sistem Informasi Biaya untuk Pengurangan Biaya Edisi 6. Universitas Gadjah Mada.

Mulyadi. 2005. Akuntansi Manajemen. Dr. I Gusti Putu Darya. Uwais Inspirasi Indonesia.

Mulyadi. 2013. Sistem Akuntansi, Edisi Ketiga. Salemba Empat, Jakarta. Mulyadi. 2014.

Akuntansi Biaya Edisi 4. Alfabeta: Universitas Gadjah Mada. Mulyadi. 2015.

Akuntansi Biaya Edisi 5. Alfabeta:Universitas Gadjah Mada.

Nanda, dkk. 2018. Analisis Penerapan Activity Based Costing System dalam Penentuan Harga Pokok Produksi pada PT. Bengawan Tex. Jurnal Akuntansi dan Sistem Teknologi Informasi Vol. 14 No. 2 Juni 2018344

Rina. Accounting, PT. Peni Regency. 2019. Perhitungan Harga Pokok Produksi dan Biaya-Biaya yang digunakan dalam pembangunan rumah.

Raba'h. Abedalqader 2013. The influence of Company Characteristics Factors to Activity Based Costing System Implementation. Journal of Education and Vocational Research Vol. 4, No. 2, pp. 36-46, Feb 2013.

Rahmadani, Nurfatimah. 2016. Penentuan Harga Pokok Produksi Pembangunan Rumah dengan menggunakan Metode Activity Based Costing (Studi pada Perum Perumnas Regional VII Makassar). Akuntansi Peradaban : Vol. II No. 1 Juli 2016. 
R. Martusa dan Agnes Adie F. . 2011. Peranan Activity-Based Costing System Dalam Perhitungan Harga Pokok Produksi Kain Yang Sebenarnya Untuk Penetapan Harga Jual. Akurat Jurnal Ilmiah Akuntansi Nomor 04.

Rotikan, R. Gloria. 2013. Penerapan Metode Activity Based Costing Dalam Penentuan Harga Pokok Produksi Pada PT. Tropica Cocoprima. Jurnal EMBA 1019 Vol.1 No.3 September 2013, Hal. 1019-1029

Sugiyono. 2018. Metode Penelitian Kuantitatif, Kualitatif, dan R\&D. Bandung: Alfabeta. (Buku)

Sugiyono. 2019. Statistika Untuk Penelitian. Bandung: Alfabeta. (Buku)

Suratinoyo Ayu W.. 2013. Penerapan Sistem ABC untuk Penentuan Harga Pokok Produksi pada Bangun Wenang Beverage. Jurnal EMBA Vol.1 no. 3 September 2013, Hal. 658-668

Utomo Supri Wahyudi, dkk. 2017. Analisis Penerapan Metode Activity Based Costing dalam Penentuan Tarif Harga Sewa Kamar Hotel. Forum Ilmiah Pendidikan Akuntansi Vol 5 no 1 Oktober 2017 hlmn. 193-202

Wulansari R. 2012. Perhitungan Harga Pokok Produksi Dalam Menentukan Harga Jual Dengan Menggunakan Activity Based Costing System 